\title{
A Comparative Analysis of the Alternative Approaches in the Provision of Agricultural Extension Service
}

\author{
Nicholas Ozor \\ Department of Agricultural Extension \\ Faculty of Agriculture \\ University of Nigeria, Nsukka, Enugu State \\ E-mails: sunny ozor@yahoo.com; nicholas.ozor@unn.edu.ng \\ Mobile: +2348035781264
}

\begin{abstract}
In a climate of declining government support for conventional provision of extension service and the evidence of lack of success of traditional methods, the need for alternative methods is recognized. This study critically examined current alternative approaches in the provision of extension service world-wide stressing the features, gains and shortcomings of each approach. The approaches considered include privatization, commercialization, decentralization (deconcentration, delegation, devolution, and transfer to private firms and NGO), and cost-sharing. One of the key features of all the reforms is that they aim at recovering a part or all of the cost of the provision of extension service so as to take the burden away from the public sector, cut down on expenses, improve management and staff professionalism, and make users' problems become main priorities. The paper further compared the approaches based on their major characteristic features and country case examples. Finally it recommended that individual countries should endeavor to make situational analysis and independent economic, political and technical determinations, not the use of implantation or formulas, in developing funding and delivery arrangements to provide for agricultural extension service.
\end{abstract}

Keywords: alternative approaches, provision, agricultural extension service

\section{Introduction}

The provision of agricultural extension service is a double-barreled concept. It involves both the delivery and financing of the system which are related to each other and inter-twined. Thus every extension service that is delivered must some how be funded and vice-versa. Such delivery or financing can either come from the public or the private sectors or a mixture of the two. The latter paradigm results in the existence of a continuum where the different stakeholders from the sectors have different levels of participation in the delivery and financing of agricultural extension service which are under pressure to change due to changes in clientele needs and the redefinition of government roles.

The failure of the traditional methods as seen in the Ministry of Agriculture (MOA) extension approach, the Local Government Area (LGA) extension approach, and most recently the Agricultural Development Programme (ADP) extension approach which are strictly government controlled, can be partly attributed to the fact that they have not always focused on farmers' priority issues, or have given recommendations that were inappropriate or with no immediate tangible benefits. The underlying reasons for these failures also are that farmers were insufficiently involved or not involved at all, in identifying their problems, or in selecting, testing 
and evaluating the possible solutions to their farm problems. These factors if corrected could motivate farmers to participate in providing funds towards the transfer of technologies in order to increase production, income and their overall standard of living.

Many countries have thus reformed their extension services to improve their relevance to farmers, and increase their efficiency, effectiveness, and impact. In many countries, extension services are moving from a supply-driven approach with government as the sole provider of funds and advice, to a much more flexible and pluralistic demand-driven strategy where all the stakeholders partake in the overall extension activity. An acceptance that the farmer as a stakeholder can, and indeed does, make important contributions at the various phases in technology development, transfer and utilization based on indigenous knowledge, effectively neutralizes the false concept of "one source knowledge and funding" in the linear model that has been the basis of several extension approaches. Development programmes worldwide have recognized that local participation is the key to the sustainable transfer and long-term adoption of new technologies and approaches. A participatory learning process therefore needs to be incorporated where farmers and other development beneficiaries have real decision-making power and are part of the problem analysis and solution generation (Röling and Pretty, 1997).

Mulhall and Garforth (2000) noted that due to the vast number of small, subsistence farmers in many countries, the burden on a state service is immense, especially the recurrent costs of supporting a large number of technical field level staff. While the unit cost of extension staff in many countries is low, large staff size translates into large government outlays. In an FAO survey of 207 agricultural extension organizations in 115 countries, 50 percent of these organizations have been established or were recognized in the previous two decades (Swanson, Farner and Bahal, 1990). As a result of financial concerns involved in the running of these large organizations, many countries have examined alternative structural arrangements, including the feasibility of reducing public sector extension expenditures with associated staff reductions, changes in tax raising, charges for government extension services and commercialization and privatization (Howell, 1985). Also, a number of countries have moved towards reducing, recovering or shifting the burden of the costs associated with provision of public sector agricultural extension, particularly transferring private good functions to private industry (Rivera and Cary, 1997).

What then are the current reforms already adopted in the provision of agricultural extension service? What are the major features and differences in these reforms? This paper therefore sought to provide answers to the above questions giving country case examples.

\section{Alternative approaches in the provision of agricultural extension service}

Examined in details below are some current alternative approaches in the provision of agricultural extension service. They include:

\section{Privatization}

Privatization is often associated with the sale of state assets or shares in public enterprises (Ozor, 2002). The sale may involve all or some of the government equity in a particular enterprise. It also involves the introduction of private capital management or management expertise into a public sector activity. However, when agricultural extension is discussed, privatization is used in the broadest sense - as a 
form of introducing or increasing private sector participation, which does not necessarily imply a transfer of designated state-owned assets to the private sector (Rivera and Cary, 1997). In other words, it is a mixed system whereby extension services are provided by both private and public sector entities with each having clearly defined roles and responsibilities. Le Gouis (1991) observed three major policies adopted by government and farm organizations regarding privatization of extension to include public financing by the taxpayer only for the kinds of services that are of direct concern to the general public; direct charging for some individual services with direct return (in the form of improved income); and mixed funding shared between public and private professional association contributions for some services where the benefits are shared.

According to Katz (2002), privatization or the withdrawal of the state from extension and other functions in the agricultural sector can take place in various ways: 1) Dismantling- staff are released and structures are abandoned. It is expected that replacement structures in the private sector will develop within a reasonable time. In many Latin American countries public extension as well as research organizations have been dismantled to a large extent. 2) Controlled privatization- this is the conscious and managed transformation of public organizations into, or their targeted replacement by, private entities. Such entities are mostly commercial enterprises, but could also be producer associations, NGOs, trust funds or foundations. A large public organization may be transformed into one large private entity, or into a number of smaller entities. Katz further noted that privatization of public services in the agricultural sector in developing countries often starts with input provision and veterinary services. In some industrialized countries public advisory services underwent controlled institutional privatization (e.g. Agricultural Development Advisory Service (ADAS) in UK).

Leeuwis (2006) observed that many governments have partly or wholly privatized their state agricultural extension service. These organizations were reorganized into profit or non-profit organizations that were independent to some degree and had to earn an important and- often gradually increasing- share of their income through the market. According to Leeuwis, important influences and arguments that play a role in bringing about privatization include:

- generally increased trust in the efficiency of market forces, combined with the perception that many public extension organizations operate in an inefficient, bureaucratic and inflexible manner, and are vulnerable to corruption, nepotism and the like;

- sufficiently high incomes in commercial agriculture for farmers to pay for agricultural advice that leads to increased profit (more in industrialized countries);

- increased specialization and less common interest among farmers (more in industrialized countries);

- agricultural overproduction and reduced public support for subsidizing the agricultural sector (more in industrialized countries);

- sufficiently high incomes among consumers, and therefore a reduced need to keep the prices of agricultural products low (more in industrialized countries);

- reduced electoral and economic importance of the agricultural sector (more in industrialized countries);

- a wish to make agricultural service provision more demand-driven and clientfriendly, and less top-down and paternalistic; 
- a wish to resolve the long standing friction that extensionists experience between being a policy implementer, acting in the government interest or being a consultant, acting in the client interest;

- a wish to open up agricultural knowledge networks (i.e. reduce the influence of agricultural lobbies of primary producers in setting extension and research agendas) in order to create more space for new concerns such as environmental issues, natural resource management, consumer concerns and chain management;

- a wish or need to reduce government spending in view of deficits, structural adjustment policies, etc; and

- a wish to reduce government responsibility and liability in the case of 'bad quality' advice.

As can be noted from the above, there are a number of arguments in favour of privatizing extension that are specific to industrial countries, implying at the same time that there is perhaps more reason to look critically at efforts to create a 'knowledge market' in developing countries (Leeuwis, 2006). Experience shows that the dismantling of public extension organizations does not automatically lead to the emergence of an extension service market with diverse private enterprises offering services to a broad clientele. Private providers of advisory services emerge in profitable niches and offer services to commercial and often specialized producers. Services that link advice with the provision of means of production and credit, as well as integrated support services around sub sector product chains become more widespread (Katz, 2002). Private arrangements may offer benefits for small farmers, but overall they favour better-off clients.

\section{Commercialization}

Commercialization involves the re-organization of a public enterprise (P.E.) and the introduction of commercial principles into its operations, including the application of user charges, commercial accounting and commercial performance objectives, with the aim of turning it into a commercially-viable and profit-making enterprise (United Nations, 1995). According to NCP (2000), full commercialization means that enterprises so designated will be expected to operate profitably on a commercial basis and be able to raise funds from the capital market without government guarantee. Such enterprises are expected to use private sector procedures in the running of their businesses. On the other hand, partial commercialization means that enterprises so designated will be expected to generate enough revenue to cover their operating expenditures. The government may consider giving them capital grants to finance their capital projects. In both full and partial commercialization, no divestment of the federal government's shareholding will be involved, and subject to the general regulatory powers of the federal government the enterprises shall: fix rate, prices and charges for goods produced and services rendered; capitalize assets; and sue and be sued in their corporate names.

In commercialization, in contrast to privatization, the agency remains public. User fees are applied to some services, whilst other services may remain public goods (Dinar, 1996). Commercialization of farmer operations gives rise to demand for specialized client-and location-specific extension services that can be provided by private for-profit firms, although the main buyers will likely be market-oriented medium and large farmers (Umali-Deininger, 1997). Farmers at this level have 
moved into a category where they are able and willing to pay for services and goods with a high level of excludability and subtractability - i.e. which have strong private good characteristics (Dinar, 1996; Beynon et al 1998). A commercialized extension service requires that changes are made in the structure of the extension organization, the nature of clientele, the range of services provided, the personnel qualifications, and the fees charged for the various services (Dinar, 1996). Examples show that in France, about three-quarters of the operating cost is collected at the farm gate through direct payments, contributions from farmer organizations, and other direct and indirect taxes on agricultural inputs and products. User fees that are determined according to a farm's viability are in use in Ireland (Phelan, 1995). Coffey and Clark (1996) reported that Australia has introduced the notion of joint funding extension projects, where clients pay for operational and non-fixed costs. Mulhall and Garforth (2000) noted that commercialization follows a path that rewards extension agents by giving them a stake in the quality of the service they provide. Also, in Ecuador, government extension agents provide agricultural inputs and technical advice through share-cropping agreements, in exchange for a share of harvest profits. Farmers provide labour, land, and water, and the extension agents provide technical advice and inputs they purchase from suppliers.

Agencies under the commercialization strategy depend for their annual budget on consulting fees received from farmers and contractual arrangements with government for the supply of policy information and rural intelligence to government. Commercialization is perceived to have had a positive effect on moving "beyond the farm gate" into an involvement of the extension staff in the entire production processing - transporting - marketing chain. There also has been a shift in focus to a client orientation and a concern to identify and produce results rather than simply engage in activities (Hercus, 1991). In general, a more commercialized approach broadens the focus of extension personnel and makes an extension service more responsive to client needs and changing economic and social conditions (Rivera and Cary, 1997).

\section{Decentralization}

Decentralization is the shifting of responsibility for the provision of extension service from a central governmental level to some regional, district or local government administrative levels. The decentralization of extension service retains the public funding and delivery that characterize the traditional centralized extension, but however, transfers the responsibility for delivery to local governments (Anderson and Feder, 2005). The primary aim of this approach is to encourage the active participation of rural people in planning, implementing, managing and monitoring extension programs. To achieve this participation, extension organizations will need to formally decentralize or transfer the control of specific program planning and management functions to the local system levels where extension programs are actually implemented (Swanson and Samy, 2004). According to Katz (2002), different degrees of shift in responsibility are possible, from operational and administrative decision-making to political control and fiscal management. Usually some structures at the central level remain.

In order to successfully decentralize a national extension system, the stakeholders need to understand the various roles and responsibilities that are expected from each quarter in the process. Differentiating between the functions of 'providing' and 'producing' public goods and services is essential in clarifying the 
process (Silverman, 1992). Making this distinction helps identify those managerial and financial tasks to be maintained at the central level, and those functions to be delegated to and produced by local level extension units. For example, Swanson and Samy (2004) noted that the central level extension organization has a comparative advantage in national priority setting, strategy formulation and financing extension. Limiting the role of the central extension organizations to these provisional functions resolves many issues related to the inability of central administration to tailor programs and delivery methods to meet the diverse needs of farmers and rural people in different areas of the country-a capacity that is essential for successful program implementation. At the same time, the local level of the extension system has a comparative advantage in designing programs to suit local conditions and in addressing local needs (i.e. producing public goods). That notwithstanding, most responsibilities can be shared between the different levels involved in the provision of the extension service.

According to Swanson and Samy (2004), three major factors are involved in decentralization:

a. transferring specific decision-making functions to local levels, starting with simple managerial functions, such as program planning and implementation; then priority setting and fund allocation; and ending with other administrative functions including accountability and financing/ co-financing;

b. encouraging public participation, reflecting the degree of authority that is transferred to rural people, starting with advisory capacity in program planning and implementation, and ending with assuming control over selected financial planning and accountability functions; and

c. expanding local government involvement, which reflects the level of control government or local institutions, including private firms and NGOs, assume for specific functions, starting with state, provincial and/or regional levels, and ending with district, county, municipal or local government levels.

The above factors are reflected in the usually mentioned four alternative institutional arrangements inherent in the decentralization approach. They include: deconcentration, delegation, devolution, and transfer to private firms and NGOs (Cohen and Peterson, 1999; Parker, 1995; Smith, 2001).

Deconcentration: In this arrangement, selected managerial functions are assigned to sub-national levels within the national agricultural extension system with the aim of transferring management and technical functions from the central to regional or local government levels. Examples of de-concentration of extension systems are reforms implemented in Trinidad and Ghana during the late 1990s (Amezah and Hesse, 2004; Seepersad and Douglas, 2004).

Delegation: Here, a semi-autonomous government agency may be assigned responsibility for providing or coordinating extension services on a territorial basis. Some managerial, priority setting and fund allocation functions are delegated to the regional or local government levels. For example in Benin, a development project launched in 1999 that targeted 250 villages empowered the local village development committees to draw up local development plans, submit funding requests and contract for extension workers (Chabeuf et al, 2004). 
Devolution: Under this arrangement, program planning, management, and cofinancing responsibilities are transferred to state, regional and local governments. These local governments have discretionary authority to exercise their responsibilities and are only bound by national policy guidelines. China, Philippines, and Venezuela are good examples of where these functions have been devolved to the lower system level. In 1993, China made each level of government responsible for funding its own extension program (Nie et al, 2004).

Transfer to private firms and NGOs: This arrangement involves the shifting of responsibilities for extension activities from the central government to private firms, farmers' associations and NGOs at different levels. Such private firms assume the responsibility of providing extension service usually on a user charge basis. In countries such as England and Wales, Australia and the Netherlands, private sector firms have become completely responsible for providing extension services. Also, farmers' associations in some European countries, such as Denmark and Sweden, carry out extension services with partial support of the government (FAO, 2000). In developing countries, decentralization of extension systems has also relied tremendously on the participation of professional and civil societies, including civil extension associations in the case of Venezuela (Saviroff and Lindarte, 2002) and civil society organizations in the case of Uganda (Nahdy, 2004). The efficiency and effectiveness in the implementation of decentralization approach is influenced by some factors which can be considered to be outside of extension control but are too vital for the success of the program. These key issues which must be addressed for decentralization to succeed include; the legal framework supporting the reform, stakeholder participation, strengthening management capacity, improving technical capacity, operational level funding, and accountability (Swanson and Samy, 2004).

\section{Cost-sharing approach}

Cost-sharing is a system where beneficiaries of services pay user fees. It is a privatization strategy where farmers participate in funding for agricultural technology transfer (Ozor, 2007). Charging farmers some nominal sum for services can encourage them to exercise their rights as information consumers and increase their voice in the management of technology generation and transfer, thereby ensuring programme effectiveness. Farmers can choose who will provide the service and agricultural technology providers, who would want to remain relevant, must respond quickly to meet the farmers' information demands thus making the market competitive. In general, this will transmit to efficient technology delivery to farmers, increased output and poverty reduction.

\section{Elements in cost-sharing approach}

Some elements are important in understanding the mechanism of cost-sharing as an alternative approach in financing extension service. They include a) the sources of funds, b) the directions in which the funds flow, c) the mode of collection of the funds, d) the clients or users of the extension service, e) the extension service and its providers, and f) the context and framework conditions (Ozor, 2006).

\section{a) Sources of finance}

The source of financing extension service can either be from public or private finances. It is public when the national or sub-national government has the responsibility of providing for the service. Also considered among public sources are 
the finances from multilateral institutions and donor countries. On the other hand, the finances are private if the responsibility of providing extension service rests on an individual, group, association, community, NGOs, or other private bodies that are devoid of state features. Examples of these two categories of financial sources for extension service are shown in Table 1.

\section{Table 1 Public and private sources of funds for extension service}

\begin{tabular}{|c|c|c|}
\hline $\mathbf{S} / \mathbf{n}$ & Public sources & Private sources \\
\hline 1 & Donor country grants & Farmers' personal sources \\
\hline 2 & Multilateral institution grants & $\begin{array}{l}\text { Community and producer } \\
\text { organizations }\end{array}$ \\
\hline 3 & Competitive research grants & $\begin{array}{l}\text { Processing, marketing and export } \\
\text { enterprises }\end{array}$ \\
\hline 4 & $\begin{array}{l}\text { General revenue, national } \\
\text { level }\end{array}$ & Input supply enterprises \\
\hline 5 & General revenue, state level & Consumers \\
\hline 6 & General revenue, local level & Charitable donations \\
\hline 7 & Commodity export taxes & Etc... \\
\hline 8 & $\begin{array}{l}\text { Other earmarked taxes, } \\
\text { Etc... }\end{array}$ & \\
\hline
\end{tabular}

Adapted and modified from Katz (2002)

\section{b) Directions of fund flow}

The funds for the provision of extension services may come from the source to the service provider, who then provides the services to a target clientele. In this case, the financing is said to be from the supply-side. On the other hand, where public funds are directed to the clientele, who then contract or buy the services from a service provider, it is regarded as demand-side financing. These arrangements are illustrated in figure 1 below.
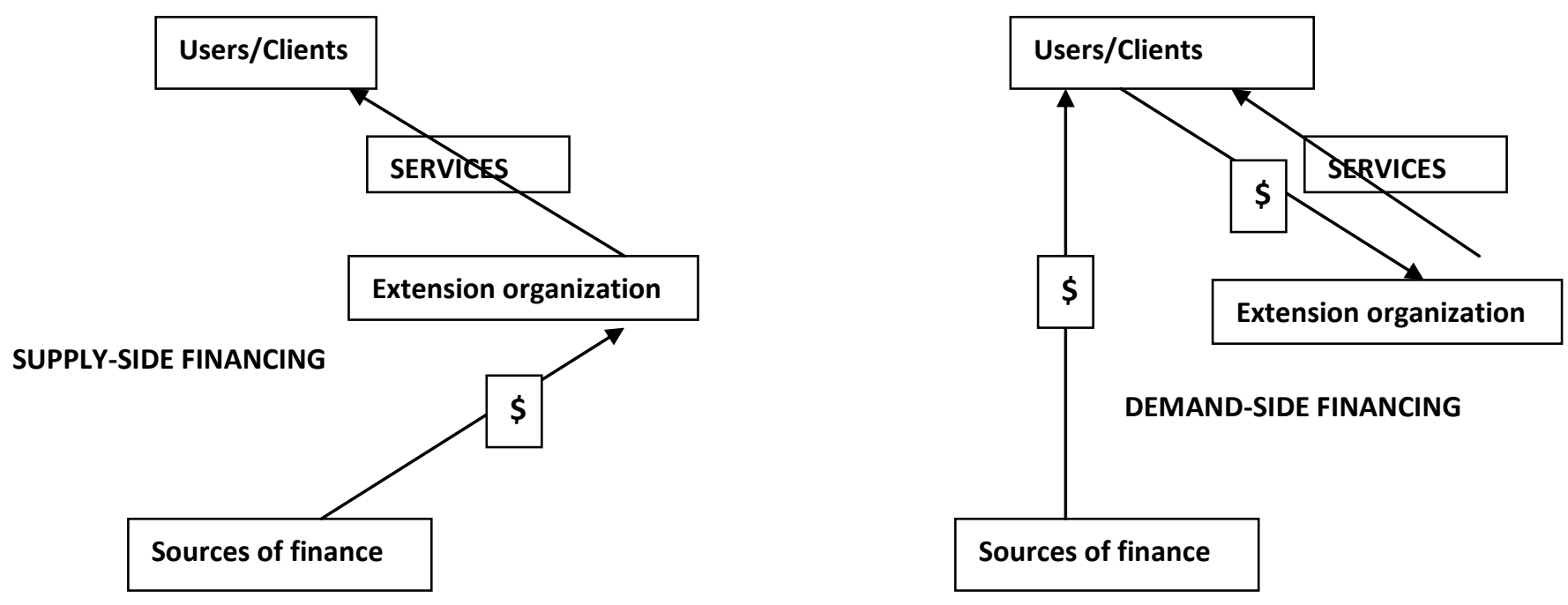

Fund flow directions

Figure 1 Direction of fund flow in extension service delivery 


\section{c) Mode of collection of funds}

Where extension services are delivered at no cost to the clientele, the mode of collection of funds is not important, but in cost-sharing arrangements or in most cases where the sources of funds are from the private finance, it becomes imperative to explore the mode through which the funds are recouped. Examples of the modes in operation in different countries are: fees for services, membership contributions in community or producer organizations, levies on marketed produce collected by producer or commodity organization, deduction from price paid to producers by processing or marketing enterprises, margin on the price of inputs, charges for a quality label, etc (Katz, 2002).

\section{d) The clientele}

There are numerous categories of end-users of agricultural extension service as a result of the wide diversity of coverage/ services offered to both rural households and commercial entities. These can range from poor farm families, to large commercial farmers, farmers' interest groups, producer organizations, women farmers, market actors, rural entrepreneurs, input suppliers, etc. A client of extension therefore is considered to be a person or group of persons who makes use of (directly or indirectly) the services offered by the extension organization. Katz (2002) listed the possible clients of extension service. She noted that in the case of extension services that lead to higher farm profits, it is obvious that the clients are individual farms. In the case of advice on management of common pasture and rangeland, for instance, the clients would be one or several village communities. A processing and marketing enterprise may be a client of extension services that help farmers to improve the quality of their products. With respect to advice on rational pesticide use on vegetables, consumers are the main clients. In the case of services for biodiversity conservation, the international community is the main client.

\section{e) Extension service and its providers}

The extension service has a vast area of coverage as it provides support services to people in rural areas so that they can make the best possible use of the resources at their disposal. These resources include cropland and gardens, livestock, forest and rangeland, as well as labour, capital, knowledge, skills, experiences and social relations. The focus of extension is mainly on advisory services and development of skills and knowledge, and less on the provision of material inputs and credit. However, the thematic areas of extension services as remarked by Katz (2002) include; production (crops, animals, inputs such as seed, seedlings, etc.), marketing, processing, farm enterprise management (financial and economic), organizational development (e.g. producer associations, joint marketing, water allocation), land and water management (e.g. soil conservation techniques, irrigation management), land use planning and management (e.g. rangeland, pastures, forests), and biodiversity conservation among others.

According to Katz (2002), the majority of services offered by extension organizations fit in one of the following five types- training, providing information, assistance in problem solving, facilitation and animation, and links to other actors. Furthermore, diverse organizations that offer these extension services fall into four major categories namely: the public and semi-public sectors, the private for-profit sector, the private non-profit sector, and the producer organizations (Table 2). 
Table 2 Providers of agricultural extension service

\begin{tabular}{|c|c|c|c|}
\hline $\begin{array}{l}\text { Public and } \\
\text { semi-public } \\
\text { sectors }\end{array}$ & $\begin{array}{l}\text { Private for- } \\
\text { profit sector }\end{array}$ & $\begin{array}{l}\text { Private non- } \\
\text { profit sector }\end{array}$ & $\begin{array}{l}\text { Producer } \\
\text { organizations }\end{array}$ \\
\hline $\begin{array}{l}\text { - National, state } \\
\text { and local } \\
\text { extension } \\
\text { organizations- } \\
\text { Ministries and } \\
\text { departments of } \\
\text { agriculture } \\
\text { - Universities } \\
\text { and research } \\
\text { institutions } \\
\text { - International } \\
\text { development } \\
\text { organizations }\end{array}$ & $\begin{array}{l}\text { - Consulting and } \\
\text { media } \\
\text { enterprises } \\
\text { - Production, } \\
\text { processing } \\
\text { and marketing } \\
\text { enterprises } \\
\text { - Input supply } \\
\text { enterprises } \\
\text { - Traders } \\
\text { associations } \\
\text { - Universities and } \\
\text { research } \\
\text { institutions }\end{array}$ & $\begin{array}{l}\text { - Local and } \\
\text { international } \\
\text { non- } \\
\text { governmental } \\
\text { organizations } \\
\text { - Religious } \\
\text { organizations } \\
\text { - Bilateral and } \\
\text { multilateral aid } \\
\text { projects } \\
\text { - Other non- } \\
\text { commercial } \\
\text { associations }\end{array}$ & $\begin{array}{l}\text { - Farmer } \\
\text { associations and } \\
\text { unions } \\
\text { - Community } \\
\text { grower } \\
\text { associations } \\
\text { - Community and } \\
\text { village } \\
\text { organizations }\end{array}$ \\
\hline
\end{tabular}

Sources: Katz (2002); Umali-Deininger (1997).

A distinction between the various providers is important because of the range of services each typically offers, and the incentives they have for delivering these services (Mulhall and Garforth, 2000). Whereas the public and semi-public sectors see extension as a public good, the private for-profit sector aims at generating profits directly or indirectly for their owners, members, or shareholders. The private nonprofit sector differs from the for-profit sector in one important respect: rather than distributing the residual earnings (if any) to individuals who exercise control, it reinvests profits to finance future activities (Umali-Deininger, 1997). The producer organizations pursue issues of group interests, seek for and disseminate information among members.

\section{f) The context and framework conditions}

The success of every privatization, commercialization or cost-sharing approach is dependent on a number of conditions which influence the process independently or in relation with other factors. Such prevailing conditions make it necessary for every government with the intention of adopting and implementing the reform approach to firstly conduct a situational analysis and come up with the country's peculiar features which will then guide the process. In order words, the conditions that favour a particular government may not do so for another government.

More specifically, the context in which an approach to cost-sharing in agricultural extension is embedded is shaped by a variety of factors which have important influence in the success of the programme. These conditions may include; the policy environment, institutional landscape, importance of agriculture in the national and local economies, fragility of eco-systems, agro-ecological systems, production systems and agrarian structures, socio-economic and cultural structures, specific agricultural and natural resource management problems (Katz, 2002), and 
the political and leadership environments. These and many more determine to a large extent the survival of a cost sharing, commercialization or privatization arrangement in any given economy and should be properly analyzed prior to the introduction of any of the reform approach.

\section{Summary of the characteristic features of the alternative approaches in the provision of agricultural extension service}

Generally, the key reforms in the transfer of agricultural technology centre around key issues including; decentralizing administration of field extension services; improving linkages among farmers, educators, researchers, extension agents and others; increasing the independence and flexibility of extension services by creating small and semi-autonomous units within government units and above all, partnerships amongst government and beneficiaries of extension services in adequately funding agro-technology delivery. The need for improved and expanded extension activities together with a strengthening philosophical view of less government involvement in national economies has led to a number of strategies for changing the way extension services are delivered. Approaches used include revitalization, commercialization (operating under user - pay commercial criteria), cost recovery, voucher systems and gradual privatization (Hercus, 1991; Wilson, 1991; Rivera and Cary, 1997; Proost and Röling, 1991). In other cases, nongovernmental organizations have been used to supplement public sector extension services, especially in the area of rural development (Amanor and Farrington, 1991). This arrangement has certain advantages for increasing extension coverage and encouraging farmer participation in technology systems.

Many country governments are therefore experimenting and implementing different processes in the provision of agricultural extension services to make it more sustainable. Table 3 shows the types of reforms currently being practiced in financing and delivery of agricultural extension service around the world, while Table 4 examines some reforms adopted by different countries and the characteristic features of each reform. 
Table 3 Types of reform in the provision of agricultural extension services

\begin{tabular}{|c|c|}
\hline Reform & Brief description \\
\hline Pluralism & $\begin{array}{l}\text { - Emergence of multiplicity of actors providing services, either } \\
\text { autonomously in response to farmer demand or facilitated by } \\
\text { government policy measures. }\end{array}$ \\
\hline $\begin{array}{l}\text { Decentralization } \\
: \\
\text { deconcentration } \\
\text { and devolution }\end{array}$ & $\begin{array}{l}\text { - Locating decision making, management authority and } \\
\text { accountability closer to the field level within public sector } \\
\text { structures (deconcentration), with the aim of making extension } \\
\text { more flexible and responsive to client need and demand. This } \\
\text { may or may not be linked to local government reform (as in } \\
\text { Uganda and The Philippines) where the funding and provision } \\
\text { of extension becomes a matter for local government structures } \\
\text { rather than central government departments (devolution). }\end{array}$ \\
\hline Cost-recovery & $\begin{array}{l}\text { Public sector service recoups some of the cost of service } \\
\text { provision from clients, in user fees from individuals or farmer } \\
\text { associations. }\end{array}$ \\
\hline $\begin{array}{l}\text { Commercializati } \\
\text { on }\end{array}$ & $\begin{array}{l}\text { - Public sector service put on a commercial and semi- } \\
\text { autonomous basis, responsible for meeting a (rising) } \\
\text { proportion of its costs from client fees and with greater freedom } \\
\text { than a government department in matters relating to personnel } \\
\text { and contract negotiation, and in the re-investment of income. }\end{array}$ \\
\hline Privatization & $\begin{array}{l}\text { - Public sector service transferred or sold to the private sector. } \\
\text { Government may continue to provide (some) funding through } \\
\text { contract arrangements. }\end{array}$ \\
\hline
\end{tabular}

Adapted from Mulhall and Garforth (2000) 
Table 4 Reforms in the provision of agricultural extension services: country case examples

\begin{tabular}{|c|c|c|}
\hline Country & Reform & Main features \\
\hline Nicaragua & Cost-recovery & $\begin{array}{l}\text { - Contracts drawn up between farmers and } \\
\text { extension providers. Farmers agree to make a } \\
\text { payment in return for the delivery of agreed-to } \\
\text { services and these payments benefit the field } \\
\text { level extension staff directly. }\end{array}$ \\
\hline Chile & $\begin{array}{l}\text { Partial } \\
\text { privatization }\end{array}$ & $\begin{array}{l}\text { - Private organizations selected by the } \\
\text { government provide services to farmers. } \\
\text { Farmers are expected to contribute something } \\
\text { towards the cost of these services. Aim is to } \\
\text { modernize agricultural practices. }\end{array}$ \\
\hline Bangladesh & Decentralization & $\begin{array}{l}\text { - Modifications to the T \& V system, use of farmer } \\
\text { groups, promotion of demand-led extension, } \\
\text { strengthening institutional links, encouraging } \\
\text { participation, increased targeting of services on } \\
\text { the poor and disadvantaged and use of a range } \\
\text { of media }\end{array}$ \\
\hline Zambia & $\begin{array}{l}\text { Partial } \\
\text { privatisation }\end{array}$ & $\begin{array}{l}\text { Privatization of some of the services previously } \\
\text { monopolized by the government to strengthen } \\
\text { extension services at field level. Government can } \\
\text { then focus on developing well trained and } \\
\text { equipped staff at the provisional and district } \\
\text { levels. }\end{array}$ \\
\hline Australia & Decentralization & $\begin{array}{l}\text { - Elements of cost-recovery, retraining of } \\
\text { extension staff, broader community and group } \\
\text { focus and decentralized decision-making }\end{array}$ \\
\hline New Zealand & Privatization & $\begin{array}{l}\text { - Complete privatization of extension services. } \\
\text { Now the responsibility of a publicly listed } \\
\text { company. }\end{array}$ \\
\hline Ireland & Commercialisation & $\begin{array}{l}\text { - In response to changing market conditions and } \\
\text { increasing commercialization the Irish advisory } \\
\text { service has developed three services, targeting } \\
\text { different groups with different needs. }\end{array}$ \\
\hline Netherlands & Privatization & $\begin{array}{l}\text { - Privatization of extension services and } \\
\text { implementation of cost-recovery mechanisms. } \\
\text { Now the service is more demand-led and there is } \\
\text { increased farmer participation. }\end{array}$ \\
\hline Albania & Commercialization & $\begin{array}{l}\text { Establishment of national public extension } \\
\text { service to deliver services, free of charge, to } \\
\text { small and medium farmers. Attempts to integrate } \\
\text { into a market economy. }\end{array}$ \\
\hline Estonia & $\begin{array}{l}\text { Partial } \\
\text { privatization }\end{array}$ & $\begin{array}{l}\text { Development of private advisory services } \\
\text { development fund, rural business information } \\
\text { centers and a pool of young, dynamic private } \\
\text { advisors }\end{array}$ \\
\hline
\end{tabular}

Adapted from Mulhall and Garforth (2000) 
Describing the public and private forms of financing communicative interventions (extension service), Leeuwis (2006) observed that the provision of communication for innovation services is becoming more pluriform. Table 5 summarizes some basic rationales and funding mechanisms for communicative interventions provided by government extension organizations, NGOs, commercial businesses, consultancy firms, producer organizations, etc. However, the rationales for providing communication for innovation services usually vary considerably among such organizations, and the same is true of the financial arrangements through which the services are paid (Van den Ban, 2000).

Table 5 Typical rationale and funding arrangements for providing extension services

\begin{tabular}{|c|c|c|}
\hline $\begin{array}{l}\text { Type of extension } \\
\text { organization }\end{array}$ & $\begin{array}{l}\text { Typical rationale for providing } \\
\text { extension services to farmers/ } \\
\text { clientele }\end{array}$ & Typical modes of funding \\
\hline $\begin{array}{l}\text { Conventional } \\
\text { government extension } \\
\text { service }\end{array}$ & $\begin{array}{l}\text { - developing/ realizing policies } \\
\text { that are considered to be in } \\
\text { the public interest (e.g. } \\
\text { economic growth) } \\
\text { controlling rural/ farming } \\
\text { populations }\end{array}$ & $\begin{array}{ll}\text { - } & \text { taxpayers money } \\
\text { - } & \text { product levies } \\
\text { - } & \text { direct fees for service } \\
& \text { (sometimes) } \\
\text { - } & \text { donor subsidies/ } \\
\text { contracts }\end{array}$ \\
\hline $\begin{array}{l}\text { Commercial input } \\
\text { providers or output } \\
\text { buyers }\end{array}$ & $\begin{array}{l}\text { - } \quad \text { securing customers } \\
\text { - } \quad \text { gelling products } \\
\text { of produceing certain qualities } \\
\text { - increasing customer } \\
\text { satisfaction with products } \\
\text { bought }\end{array}$ & $\begin{array}{l}\text { - incorporating costs of } \\
\text { services in selling/ } \\
\text { buying prices } \\
\text { - making advisory } \\
\text { services part of } \\
\text { contract farming }\end{array}$ \\
\hline Non-profit NGOs & $\begin{array}{l}\text { - } \quad \text { realizing certain political/ } \\
\text { - } \text { developmental aspirations } \\
\text { - } \text { maintaining jobs for staff } \\
\text { access to resources }\end{array}$ & $\begin{array}{ll}\text { - } & \text { donor subsidies/ } \\
\text { contracts } \\
\text { - } \\
\text { donations from } \\
\text { individuals } \\
\text { - } \text { membership fees } \\
\text { - } \text { government subsidies/ } \\
\text { contracts }\end{array}$ \\
\hline Farmers' associations & $\begin{array}{l}\text { - } \quad \text { providing support to } \\
\text { members } \\
\text { - influencing policy }\end{array}$ & $\begin{array}{l}\text { - } \text { membership fees } \\
\text { - donor subsidies/ } \\
\text { contracts } \\
\text { - government subsidies/ } \\
\text { contracts }\end{array}$ \\
\hline $\begin{array}{l}\text { Private extension } \\
\text { services/ consultancy } \\
\text { firms/ publishers }\end{array}$ & $\begin{array}{l}\text { - } \quad \text { satisfying an apparent need } \\
\text { - } \quad \text { maintaining jobs for staff } \\
\text { - making profits }\end{array}$ & $\begin{array}{ll}\text { - } & \text { direct fees for service } \\
\text { - } & \text { contracts with } \\
\text { - } & \text { covernments } \\
\text { commets with } \\
\text { organizations } \\
\text { - } \text { journal subscriptions }\end{array}$ \\
\hline
\end{tabular}




\section{Conclusion and Recommendations}

Based on the alternative approaches already reviewed, it is imperative that individual countries should endeavor to make situational analysis and independent economic, political and technical determinations, not the use of implantation or formulas, in developing funding and delivery arrangements to provide for agricultural extension service. Invariably more need to be done in order to achieve acceptability of the reforms, with due sensitivity to the differing capacities and attributes of African countries. Extension professionals, agricultural administrators and policy makers in Nigeria are therefore challenged to design the best reform for our extension system after due consideration to our peculiar circumstances, careful study of each reform and its characteristics and experiences from other countries where the reform is in practice. However, adopting an integrated approach that will involve both public and private sectors in the funding and provision of extension services may be more sustainable for the Nigerian system.

\section{References}

Amanor, K and Farrington, J. (1991) NGOs and agricultural technology development. In: W.M. Rivera and D.J. Gustafson (eds). Agricultural Extension: Worldwide Institutional Evolution and Forces for change. Amsterdam: Elsevier.

Amezah, K. and J. Hesse (2004) Reforms in the Ghanaian Extension System. In: Rivera, William and Alex Gary (eds) Decentralized Systems: Case studies of international initiatives. Agriculture and Rural Development Discussion Paper 8. Extension Reform for Rural Development. Washington D.C. The World Bank.

Anderson Jock R. and Gershon Feder (2005) Agricultural extension. In Robert E. Evenson, Prabhu Pingali and T. Paul Scultz (eds) Handbook of Agricultural Economics, Vol. 3.

Beynon, J. with S. Akroyd, A. Duncan., S. Jones (1998) Financing the Future. Options for Agricultural Research and Extension in Sub-Saharan Africa.

Oxford: Oxford Policy Management, Oxford.

Chabeuf, Noel, Josef Toledano, Yahia Bouarfa, and Hope Neighbor (2004) Benin: faster and less costly community development, In William Rivera and Alex Gary (Editors) Demand- driven approaches to agricultural extension: Case Studies of international initiatives Agriculture and Rural Development Discussion Paper 10 Extension Reform for Rural Development. The World Bank, Washington D C: 7-9.

Cohen, J .M., and S. B. Peterson (1999) Administrative Decentralization: Strategy for Developing Countries. West Hartford, Connecticut: Kumarian.

Coffey, S.G. \& R.A. Clark (1996) 'Re-engineering an extension service'. Paper presented at a workshop on Alternative mechanisms for funding and delivering extension, June 1996, Washington D.C.: The World Bank.

Dinar, Ariel (1996) Extension commercialization: How much to charge for extension services. American Journal of Agricultural Economics, Vol. 78 1-12. American Agricultural Economics Association, USA.

Food and Agricultural Organization of the United Nations (FAO) (2000) In W. M. Rivera, M. K. Oamar, and L. Van Crowder (eds.), Agricultural and Rural Extension Worldwide: Options for Institutional Reform in the Developing Countries. Rome: Food and Agricultural Organization of the United Nations. 
Hercus, J.M. (1991) The commercialization of government agricultural extension services in New Zealand In: W.M. Rivera and D.J. Gustafson (eds).Agricultural Extension: World - wide Institutional Evolution and Forces for Change. Amsterdam: Elsevier.

Howell, J. (1985) Recurrent Costs and Agricultural Development. London: Overseas Development Institute.

Katz, Elisabeth (2002) Innovative Approaches to Financing Extension for Agriculture and Natural Resource Management. Switzerland; LBL, Swiss Center for Agricultural Extension: 135Pp.

Le Gouis, M. (1991) Alternative financing of agricultural extension: Recent trends and implications for the future. In: W.M. Rivera and D.J. Gustafson (eds). Agricultural Extension Worldwide: Institutional Evolution and Forces for Change. Amsterdam: Elsevier.

Leeuwis, Cees (2006) Communication for Rural Innovation: Rethinking Agricultural Extension, Third Edition. Blackwell Publishing. The Netherlands: 329-349.

Mulhall, A E, and Garforth, C J, (eds.) (2000) Equity implications for reforms in the financing and delivery of agricultural extension services. Final Technical Report on research project R6470 to the Department for International Development. Reading. Agricultural Extension and Rural Development Department, The University of Reading.

Nahdy, S. (2004) Case Study on the Role of Agricultural Extension in Rural Development. The Uganda National Advisory Services (NAADS). In: Rivera, William and Alex Gary (eds) Decentralized Systems: Case studies of international initiatives. Agriculture and Rural Development Discussion Paper 8. Extension Reform for Rural Development. Washington D.C. The World Bank.

National Council on Privatization (NCP) (2000) Privatization Handbook. (2 ${ }^{\text {nd }}$ Edition). Abuja NCP Secretariat: 1 - 2.

Nie, C., B. E. Swanson, and Y. Feng. (2004) Financing of Extension: Lessons from China. In: Rivera, William and Alex Gary (eds) Decentralized Systems: Case studies of international initiatives. Agriculture and Rural Development Discussion Paper 8. Extension Reform for Rural Development. Washington D.C. The World Bank.

Ozor, N. (2002) Extension professionals' perception of privatization and commercialization of agricultural extension service in Enugu state agricultural development programme (ENADEP). An MSc Dissertation, Department of Agricultural Extension, University of Nigeria, Nsukka.

Ozor, N. (2006) Cost-Sharing as an Alternative Approach to Financing Agricultural Technology Transfer in Nigeria. A PhD Thesis submitted to the University of Nigeria, Nsukka and The University of Reading, United Kingdom.

Ozor, N., A.E. Agwu, N.A. Chukwuone, M.C. Madukwe and C.J. Garforth (2007) Cost-sharing of Agricultural Technology Transfer in Nigeria: Perceptions of Farmers and Extension Professionals. Journal of Agricultural Education and Extension Vol. 13, No.1, Routledge, Taylor and Francis Group, UK, 23 - 37.

Parker, A. (1995) "Decentralization: The Way Forward for Rural Development." Policy Research Working Paper 1475. Washington DC: The World Bank.

Phelan, J.F. (1995) Are traditional extension series dead or do they have a role in rural development? European Journal of Agricultural Education and Extension 2(3):7-14. 
Proost, J. and Röling, N. (1991) "Going Dutch" in extension. Interpaks Interchange 9, (1): $3-4$.

Saviroff, M,. and E. Lindarte (2002) Reforming National Extension: The Recent Experience of Venezuela. Extension Case Study.

Seepersad, J., and V. Douglas. (2004) Decentralization of the Extension Services in Trinidad. In: Rivera, William and Alex Gary (eds) Decentralized Systems: Case studies of international initiatives. Agriculture and Rural Development Discussion Paper 8. Extension Reform for Rural Development. Washington D.C. The World Bank.

Silverman, J. (1992) Public Sector Decentralization. Economic Policy and Sector Investment Programs." World Bank Technical Paper No. 188. Africa Technical Development Series. Washington DC: The World Bank.

Smith, L. (2001) Reform and Decentralization of Agricultural Services: A Policy Framework. Rome: Food and Agriculture Organization of the United Nations.

Swanson, B.E., Farner, B.J. and Bahal, R (1990) The current status of agricultural extension Worldwide. In: B. E. Swanson (ed.) Report of the Global Consultation on Agricultural Extension, Rome: FAO.

Swanson, Burton E. and Samy Mohamed M. (2004) Introduction to decentralization of agricultural extension systems: key elements for success. In: Rivera, William and Alex Gary (eds) Decentralized Systems: Case studies of international initiatives. Agriculture and Rural Development Discussion Paper 8. Extension Reform for Rural Development. Washington D.C. The World Bank.

Rivera,W.M. and J.W. Cary (1997) Privatizing agricultural extension. In: B.E. Swanson, R.P. Bentz, and A.J. Sofranco (eds). Improving Agricultural Extension - A Reference Manual, Rome: FAO: 203-211.

Röling, N., and Pretty, J. N. (1997) Extensions' role in sustainable agriculture development. In: B. E. Swanson, R. P. Bentz, and A. J. Sofranko (eds.) Improving Agricultural Extension: A Reference Manual. FAO: 181 - 191.

Umali, Deininger (1997) Public and private agricultural extension: partners or rivals? The World Bank Research Observer 12(2) 203 - 224.

United Nations (1995) Comparative Experiences with Privatization - Policy Insights and Lessons Learned, United Nations Conference on trade and development. New York and Geneva: 241 pp.

Van den Ban, A.W. (2000) Different Ways of Financing Agricultural Extension. AgREN: Agricultural Research and Extension Network Paper 106b. Overseas Development Institute (ODI), London.

Wilson, M. (1991) Reducing the costs of public extension services: initiatives in Latin America. In W.M. Rivera and D. J. Gustafson, (eds.) Agricultural Extension Worldwide: Institutional Evolution and Forces for Change: Amsterdam: Elsevier. 